\title{
JUURNAL.RU
}

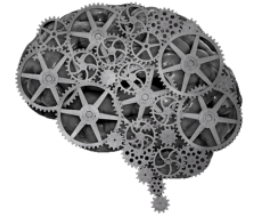

COMPANY GROUP "INTELLEKT"

\author{
Гебенова О.Д., Узденова Ф.М. \\ Карачаево-Черкесский государственный университет имени У.Д. Алиева \\ Карачаевск, Россия
}

doi: 10.18411/1j2016-4-40

\section{Оценка туристско-рекреационных ресурсов в интересах развития туризма в Карачаево-Черкесской республике}

Если под рекреацией понимается расширенное воспроизводство сил человека - физических, интеллектуальных и эмоциональных, то возможности Карачаево-Черкессии в этом неограниченны.

Рассмотрим в этом плане самые важнейшие факторы и моменты. Начнём с Кубанского ущелья и с рукотворных объектов - это плотина головного сооружения Большого Ставропольского канала и, как его называют «главным огородом» Москвы, тепличного комбината «Южный», плотины Большого Ставропольского канала. Долина реки Кубань насыщена нарзанными источниками - с.Важное, с. Красногорка, ущелье Индыш, ущелье Джалан-Кол, a. Карт-Джурт, ущелье Махар. Множество исторических памятников сторожевые казачьи башни в станице Красногорской, в а.Сары-Тюз, в а. Каменномост, в пос. Новый Карачай. Небольшая по территории КарачаевоЧеркесия насыщена комплексом природных и рукотворных объектов для воспроизводства интеллектуальных, эмоциональных и физических сил. Рассмотрим важнейшие факторы, начав с долины Кубани где имеются: цементный завод - один из крупнейших заводов России,Шоанинский монастырь, башня в а. Хурзук, останки железнодорожных мостов узкоколейной железной дороги - Черкесск-Сухуми, строительству которой помешала война, более современное сооружение - Музей памятник защитникам Кавказских 
перевалов у пос. Орджоникидзевский. Имеются древние городища Хумаринское и Гилячское, которые описаны в археологической литературе и неописанное- в урочище Джаныкку (16 км.от Карачаевска). Имеются запасы различных полезных ископаемых: барит, сурик, гранит, каменный уголь, цинк, свинец, серебро и др.

В Бассейне Кубани можно совершать различные путешествия: по долинам Учкулана, Уллу-Кама и Хурзука проходят туристские пути к озеру Уллу-Кёл, источникам нарзана у северного подножия Эльбруса, в долины Махара, Гондарая, Узун-Кола, в Кабардино-Балкарию, в Абхазию через перевал Махар. Местность, где расположены аулы Карт-Джурт, Учкулан, Хурзук отличается сухостью климата, бедностью природы и суровостью ландшафта. За год здесь выпадает осадков в два раза меньше, чем в Теберде. Другой вид имеет природа Maхара, Гондарая, Узун-Кола, Уллу-Кама. Они отличаются более благоприятным климатом, богатством хвойных лесов, что очищает воздух. Махарские нарзаны имеют довольно большой дебит и издавна использовались местными жителями для лечения различных заболеваний. Эти источники можно использовать на промышленной основе. Это привлечёт большой поток туристов.

Тебердинское ущелье и окрестности Домбая наиболее изученное и исхоженное место не только жителями России, но и туристами из других стран, начиная ещё с древних времён. Например, о тропе через Клухорский перевал упоминает греческий учёный Страбон ещё в I веке до н.э., а французский монах, посол к монголам короля Людовика ІХРубрук в 1253 году писал, что монголы не сумели завоевать полностью аланов. В а.Нижняя Теберда Сентинский храм XXI веков, Амгатинское городище, Алибекское городище, памятники скифского времени в Домбае говорят о том, что долина Теберды ещё с незапамятных времён была густо заселена. Это упоминается и в стихотворении М. Лермонтова «Велик богат аул Джемат, он никому не платит дани, его кинжал - стальной булат».

Из Теберды и Домбая имеются множество радиальных и линейных 
туристских маршрутов: в соседние ущелья Кубани, Марухи, Архыза, на водопад Чучхур, Кругозоры Мусса-Ачитара, Семёнов-Баши, ледник Алибек, Бадукские озёра, водопад Хутый, Муруджинскиеозёа, Джамагатские нарзаны, Клухорские озёра,и перевал и др. Через Теберду, Домбай, Клухорский перевал проходил всесоюзный линейный туристский маршрут №43, очень увлекательна прогулка по Теберде с посещением музея И.Крымшамхалова и музея заповедника с вольерами, где содержатся дикие звери. Канатная дорога на кругозоре Мусса Ачитара позволяет туристам летом и зимой любоваться красивой панорамой Главного Кавказского хребта, Тебердинского ущелья, а в хорошую погоду и вершиной Эльбруса. Зимой здесь раздолье горнолыжникам - как новичкам, так спортсменам-разрядникам и мастерам. С постройкой новой линии канатной дороги возможности приёма гостей стали ещё больше. Туристские маршруты позволяют повышать спортивное мастерство от новичков до мастеров спорта.

Климатические особенности района Теберды и Домбая отличаются мягкостью и большим количеством солнечных дней 325-330, которых больше, чем в Кисловодске 315-320. А воды водопадов низвергающихся с ледников, падающие с большой высоты, разбрызгивая дистиллированную воду, создают отрицательные ионы, которые благоприятно воздействуют на человека.

Район Архыза, как Теберду и Домбай, даже швейцарцы-знатоки туризма, называют жемчужиной Кавказа. Рекреационными достопримечательностями этого района, несомненно, являются: РАТАН-600 (радиоастрономический телескоп академии наук); САО (специальная астрофизическая обсерватория), способная «разглядеть» зажжённую спичку на расстоянии 10 километров.

Нижне-Архызский архитектурно-археологический комплекс. Из Архыза можно совершать прекрасные путешествия как радиальные, так и линейные. Архызский кругозор, долина реки София, Нижне-Архызские древние храмы, плато Габулу, Баритная балка, Лунная долина и много других- это радиальные маршруты. Архыз-Теберда-Домбай, Архыз-Красная поляна, Архыз-озеро Рицалинейные (бывшие всесоюзные) маршруты. Учёными доказано, что Нижний 
Архыз являлся центром Аланского государства и через него проходил великий шёлковый путь.

В Архызском лесу преобладает сосна, а, как известно, в сосновом бору воздух стерилен от всяких вредных бактерий. Архызский лес является ценным даром природы. Здесь имеются экземпляры пихты, достигающие 60 метроввысоты, 1,5 метра в обхвате, отдельные экземпляры имеют возраст до 700 лет, имеются реликтовые растения третичного периода - кавказская пихта, ель, тис.

Обилие солнца в течение года (особенно летом всего 13 дней пасмурных), почти полное отсутствие туманов, затяжного ненастья, сильных ветров, относительно тёплая зима- всё это ставит долину Архыза в ряд лучших климатических мест республики и России в целом. Лунная долина, Софийское ущелье - отличные места для горнолыжников, а туристские маршруты, как и в районе Теберды и Домбая дают возможность повышать спортивное мастерство от новичков до мастеров спорта. Но всё это не используется. А был проект строительства в Архызе крупнейшей базы отдыха, туризма и горнолыжного спорта, большой стадион для конькобежных соревнований, малый стадион для фигурного катания, три хоккейных поля, трамплины для прыжков на лыжах, канатные дороги к лыжным трассам.

Если вернуться к этим планам и осуществить их, то рекреационные возможности республики намного повысятся.

Недостроенная 8-этажная турбаза на 400 мест в Архызе стоит как памятник безобразного отношения к организации туризма.

Долина Большой Лабы- второй по многоводности и протяжённости после Кубани реки республики, в туристском плане освоен меньше, чем Теберда, Домбай, Архыз, хотя это не умаляет его рекреационных возможностей.

Верховье долины Большая Лаба было известно людям с глубокой древности, что подтверждено археологическими находками на берегах реки Пхия. Ещё во время нашествия скифов в пределы Малой Азии по перевальным 
тропам они в нескольких местах пересекали Кавказский хребет и выходили на Черноморское побережье. Одним из таких путей являлась и река Большая Лаба, так как в верхнем её течении имеются известные с незапамятных времён перевальные пути, ведущие в древнюю Колхиду. Верховья долины защищены высокими горными хребтами от проникновения в неё холодных северных и северо-восточных ветров, с юго-западной стороны открыт доступ влажным воздушным массам с Чёрного моря. Поэтому долина отличается мягким и влажным климатом. В среднем за год осадков здесь выпадает около 1000 мм., что на 260 мм.больше, чем в Архызе. Благоприятные погодные условия, красивая природа, богатство растительности, обилие грибов и ягод, делают долину Большой Лабы замечательным районом для отдыха и туризма. Отсюда ведут линейные и радиальные туристские маршруты. Большой популярностью пользуются источники нарзана на берегу реки Лаштрак - более 10 видов минеральной воды, сильно насыщенных углекислотой. Правда, эти источники используются самыми дедовскими способами и, в основном, жителями республики. При благородном использовании этих источников можно организовать массовое посещение туристов и получать с этого большую прибыль.

Рекреационные возможности республики будут не раскрыты полностью, если не упомянуть о сочных альпийских лугах всей республики, трава которых является отличным кормом для диких и домашних животных. Недаром мясо карачаевской породы овец считалось деликатесом в ресторанах Парижа, Санкт Петербурга и Москвы ещё и в царские времена.

Для реализации рекреационных ресурсов Карачаево-Черкесии целесообразно возродить конный прокат. Тем более что для этого имеется базы.

Необходимо объявить районы Узун-Кола, Уллу-Кама, Махара, Теберды, Домбая, Марухи, Аксаута, Большой Лабы, Архыза зоной туризма и отдыха. Прекратить любую вырубку леса. 
Если вырубка леса будет продолжаться такими темпами как сейчас, то, как говорил французский деятель Шатобриан «Леса предшествовали человеку пустыни следуют за ним», от туристских зон действительно останутся пустыни.

Для туристско - рекреационной зоны верховьев всех рек КарачаевоЧеркесии необходимо выделить ионизационный режим атмосферы.

При оценке климатических достоинств местности, которую выбирают для рекреационной сферы, немаловажное значение имеет ионизационный режим атмосферы.

Из всего сказанного следует, что в Карачаево-Черкесии можно организовать туризм, который может удовлетворить самые взыскательные запросы (может за исключением звёздных отелей) любого вида туризма пешего:спортивного (как новичков, так и разрядников), познавательного, оздоровительного отдыха, экологического, религиозного, автомобильного, мотоциклетного; велосипедного, конного, сплава по реке (рафтинга), спелеотуризма.

\section{Литература:}

1. Гридина Е.В. Карачаево-Черкесский рекреационный район // Рекреационные ресурсы. - Ростов н/Д, 2002.

2. Диброва Г.С., Фогилев Э.А. Из истории рекреационного освоения Северного Кавказа // Рекреационные ресурсы: условия и ресурсы отдыха и туризма. Ростов н/Д: Издательство «РГУ», 2002.

3. Ефремов Ю.В., Беликов М.Ю. География Кавказа: вчера, сегодня, завтра. // Материалы учредительного Съезда Русского Географического Общества - М., 2010.

4. Уникальные территории в культурном и природном наследии регионов.- М.: Российское НИИ культурного и природного наследия, 2004.

5. Эколого-географический атлас Карачаево-Черкесской республики. -Ростов н/Д, 2001. 